\title{
Antioxidant capacity, reproductive response and glucose concentration and insulin of ewes supplemented prior to insemination with orange residue
}

\author{
[Capacidade antioxidante, resposta reprodutiva e concentração de glicose e insulina de \\ ovelhas suplementadas antes da inseminação com resíduo de laranja]
H.M. Rodríguez-Magadán ${ }^{(\mathbb{D})}$, T. Salinas-Rios ${ }^{1 *}$ (D) , J. Hernández-Bautista ${ }^{1}$ (D) S. Cadena-Villegas ${ }^{(\mathbb{D})}$, J. Herrera-Pérez ${ }^{3}$ (D) R. Nieto-Aquino ${ }^{4}$ (D) J. Marín-Sánchez ${ }^{1}$ (D) \\ ${ }^{1}$ Facultad de Medicina Veterinaria y Zootecnia - Universidad Autónoma Benito Juarez de Oaxaca - Oaxaca, México \\ ${ }^{2}$ Maestría en Ciencias en Producción Agroalimentaria en el Trópico, Colegio Postgraduados Campus Tabasco \\ ${ }^{3}$ Facultad de Medicina Veterinaria y Zootecnia - Universidad Autónoma de Guerrero - Guerrero, México \\ ${ }^{4}$ Instituto Tecnológico de Huejutla - Tecnológico Nacional de México - Huejutla, México
}

\begin{abstract}
The objective was to evaluate the antioxidant capacity, glucose and insulin concentration and reproductive performance of ewes supplemented with orange residue prior to insemination. Fifty-five multiparous ewes were divided into two corrals, and 15 unbred ewes were kept individually to measure feed consumption. Two integral diets were administered; T0: control treatment and T1: with $20 \%$ of dry matter of orange residue. Ten days after the start of supplementation, the ewes were synchronized. Supplementation was finalized prior to artificial insemination, then, a blood sample was taken to measure the antioxidant capacity and glucose and insulin concentration. An analysis of variance was made to evaluate the effect of treatment on the antioxidant capacity, glucose and insulin; and to analyze the response to estrus, percentage of gestation and prolificity a ji squared test was performed. Of 9 antioxidant compounds found in the orange residue, hesperidin $(7.44 \%)$, chlorogenic acid $(0.50 \%)$ and protocatechuic acid had the highest concentration. Feed intake, estrus response, percentage of gestation, antioxidant capacity, and glucose and insulin concentration were not affected by the treatment. It is concluded that inclusion of $20 \%$ of orange residue in the diet prior to insemination in ewes is possible.
\end{abstract}

Keywords: citruses, sheep, byproducts, synchronization of estrus

\section{RESUMO}

O objetivo deste estudo foi avaliar a capacidade antioxidante, a concentração de glicose e insulina e o comportamento reprodutivo de ovelhas suplementadas com resíduo de laranja antes da inseminação. Cinquenta e cinco ovelhas multiparas foram divididas em dois currais e 15 ovelhas sem raça foram mantidas individualmente para se medir o consumo de ração. Duas dietas integrais foram administradas; T0: tratamento controle e T1: dieta com 20\% de resíduo de laranja seco. Dias após o início da suplementação, as ovelhas foram sincronizadas. A suplementação foi finalizada antes da inseminação artificial e, em seguida, foi coletada uma amostra de sangue para medir a capacidade antioxidante e a concentração de glicose e insulina. Uma análise de variância foi feita para avaliar o efeito do tratamento sobre a capacidade antioxidante, a glicose e a insulina, e um teste do ji quadrado foi realizado para analisar a resposta ao estro, a porcentagem de gestação e de prolificidade. Dos nove compostos antioxidantes encontrados no resíduo laranja, a hesperidina (7,44\%), o ácido clorogênico (0,50\%) e o ácido protocatecuico foram os de maior concentração. O consumo alimentar, a resposta ao estro, a porcentagem de gestação, a capacidade antioxidante, a concentração de glicose e a insulina não foram afetados pelo tratamento. Conclui-se que é possível a inclusão de $20 \%$ de resíduos de laranja na dieta antes da inseminação em ovelhas.

Palavras-chave: citrinos, ovelhas, subprodutos, sincronização de estro

*Corresponding author: salinas980@ hotmail.com

Submitted: July 18, 2020. Accepted: March 11, 2021. 


\section{INTRODUCTION}

It has been demonstrated that food supplementation prior to insemination improves the reproductive response of ewes. Thus, Venter and Greylin (1994) observed improvement in the reproductive parameters after supplying ewes for three weeks a diet with $2.83 \mathrm{Mcalkg}^{-1}$ and $11.7 \%$ of PC. Khursheed et al. (2013) report that supplementation with a concentrate with $13.1 \%$ of PC and $3.69 \mathrm{Mcalkg}^{-1}$ of EM at $1.5 \%$ of live weight for 35 days increments the ovulatory rate and the glucose concentrations and urea in blood. Supplementation is even more necessary when the ewes are going to be inseminated shortly after weaning, given that during lactation there is a loss in corporal condition if supplementation is not made with the necessary energetic requirements (Boscaro et al., 2012), causing the delay of the estrus cycle. Although the benefit of supplementation during this stage is widely known, frequently it is not administered due to high costs and lack of availability of the conventional ingredients. This makes it necessary to find alternative ingredients that can reduce the costs of supplementation, and various byproducts have been evaluated in animal feed.

In the process of transformation of products for human consumption, residues are generated which can become a problem of environmental contamination if they are not adequately treated. Among these byproducts is orange residue, which according to the FAO (Food..., 2017), in 2015, on a world scale, there was a production of $68,600,000$ tons, of which $19,911,100$ were processed. Mexico produced 4,158,000 tons, of which only $1,225,000$ were processed. In the extraction of orange juice for packaging or immediate consumption, approximately $50 \%$ residue is produced, comprised of peel, seeds and pulp residue.

These byproducts have been tested in sheep, where it is reported that its inclusion of up to $72 \%$ in a concentrate that provides $1 \%$ of the live weight, does not affect weight gain (Nordi et al., 2014). On the other hand, positive effects on the digestibility and consumption of feed have been reported when $22 \%$ of orange pulp (Tadayon et al., 2017) is included in the feed, in sheep's milk the percentage of fat and non-fatty solids improves (Volanis et al., 2006); furthermore, the cheese of goats supplemented with orange pulp has a higher level of acceptance (Salvador et al., 2014).

Due to the above-mentioned importance of feed supplementation prior to insemination in ewes and the scant information existing of supplementation with orange residue in animals in reproduction, its evaluation during this stage is necessary. In addition to the benefit of reducing costs, the different parts of orange residue contain antioxidants (Seok-Moon et al., 2004; EscobedoAvellaneda et al., 2014). In humans, where more studies have been made on oxidative stress, it has been reported that the concentration of malondialdehyde (which is an indicator of oxidation) is higher in infertile women (Veena et al., 2008), whereas in sheep it has been demonstrated that in the first days of gestation there is a drop in the antioxidant capacity in blood plasma (Salinas-Rios et al., 2016).

Therefore, it is necessary for the ewes to be brought to insemination with an adequate oxidative stability, thus the inclusion of orange residue, in addition to reducing costs of supplementation, could have benefits in reproduction due to the presence of antioxidants. Therefore, the objective of the present study was to evaluate the supplementation with orange residue in the antioxidant capacity, glucose concentration and insulin and reproductive behavior of ewes prior to insemination.

\section{MATERIALS AND METHODS}

The study was conducted in Valles Centrales of Oaxaca, Mexico, located between the coordinates $17^{\circ} 05^{\prime} 00^{\prime \prime} \mathrm{N}$ and $96^{\circ} 45^{\prime} 00^{\prime \prime} \mathrm{W}$. The study was made with regional sheep breeders, who prior to the study had maintained the sheep with feed based on bales of corn stubble, bean, alfalfa and hay. The animals used in the study were fifteen unbred and 55 multiparous ewes between 2 and 4 births, with a corporal condition of 3 to 4 (scale of 1 to 5 according to the description of Russel et al.,1969), crosses of Dorper, Katahdin and Pelibuey. The multiparous ewes had been weaned an average of 1 month anticipation prior to the start of the experiment.

The orange residue was collected during a week in juice stands near the study site. This residue consisted of peel, pulp residue and seed that remained from the orange after the juice was 
extracted. On the same day it was collected, the residue was placed to dry in the sun and after was ground. Next, dry matter, ash and crude protein were determined (Official..., 1990), along with neutral detergent fiber and acid detergent fiber (Van Soest et al., 1991).

For the determination of antioxidant compounds, $0.5 \mathrm{~g}$ of dehydrated and ground sample was weighed, $5 \mathrm{~mL}$ of $\mathrm{H}_{2} \mathrm{O}$ were added, and agitated for 20 minutes. Next, it was centrifuged at 5,000 rpm for 10 minutes and the supernatant was recovered. The determination was made by liquid chromatography using two columns, a nucleosil $100 \mathrm{~A}, 125$ x 4.0mm internal diameter (MachereyNagel) for detection of phenolic acids, and for flavonoids, a hypersil column ODS $5 \mu \mathrm{m}$ of particle diameter, $125 \times 4.0 \mathrm{~mm}$ internal diameter (Agilent Technologies). Seventeen compounds with antioxidant properties (Sigma) were used for the construction of the standard curve, which included the following: rutin, florizine, myricetin, quercetin, naringenin, floretin, galangin, gallic acid, chlorogenic acid, syringic acid, vanillic acid, p-hydroxybenzoic acid, caffeic acid, ferulic acid, p-coumaric acid, protocatechuic acid and hesperidin.
Fifty-five multiparous ewes, crosses of Dorper, Katahdin and Pelibuey, were separated into two groups in corrals with automatic water dispensers and metallic feed troughs. Treatments consisted of T0 $=$ control diet $(n=27)$ and T $1=$ diet with $20 \%$ dry matter of orange residue $(\mathrm{n}=28)($ Table 1$)$. Similarly, 15 primiparous ewes $(37+2.7 \mathrm{~kg})$ were kept in individual stalls (T0: $\mathrm{n}=8$; T1: $\mathrm{n}=7$ ) in order to measure if in addition to the effects on reproductive behavior, antioxidant capacity and glucose concentration and insulin, the orange residue could affect feed intake. During the first week the ewes were adapted to the diet, in which the integral diet was gradually increased, and the amount of fodder (bean, maize and alfalfa stubble) was reduced. In the 3 following weeks, supplementation and water were supplied at free access. Both diets contained $12 \%$ protein and 2.2 $\mathrm{Mcal} / \mathrm{EM} / \mathrm{kg}$. The diet in the ewes kept ingroups and in individual stalls was provided at free access daily with trough readings at 8:00 and 18:00. Supplementation finalized 12 hours prior to artificial insemination. After artificial insemination, the animals were fed as the breeders had done prior to the study.

Table 1. Diet composition used to feed hair ewes before breeding with and without dehydrated orange residue

\begin{tabular}{lcc}
\hline \multicolumn{1}{c}{ Ingredients } & T0 & T1 \\
\hline Maize grain (\% WM) & 22.83 & 15.79 \\
Soybean paste (\% WM) & 3.44 & 10.85 \\
Alfalfa (\% WM) & 34.44 & 3.95 \\
Maize stubble (\% WM) & 26.57 & 38.48 \\
Orange residue in flour (\% WM) & 0.00 & 19.73 \\
Urea (\% WM) & 0.98 & 0.99 \\
Common salt (\% WM) & 1.93 & 1.93 \\
Molasses (\% WM) & 9.80 & 8.29 \\
\hline
\end{tabular}

WM: Wet matter. T0 $=$ control diet and T1 $=$ diet with $20 \%$ dry matter of orange residue.

Ten days after having initiated feeding with integral diet, an intravaginal applicator impregnated with $0.3 \mathrm{~g}$ of progesterone $\left(\mathrm{CIDR}^{\circledR}\right)$ was inserted to both groups of ewes. Ten days after the insertion of progesterone, $125 \mu \mathrm{g}$ of cloprostenol sodium was applied via intramuscular injection to each ewe. The applicator was removed on the twelfth day after insertion and $200 \mathrm{Ul}$ of eCG (Novormon ${ }^{\circledR}$ ) were applied. Twenty-four hours after its removal and every 6 hours, estrus detection was performed with rams covered with an apron to prevent copulation. The ewes were inseminated through laparoscopy at fixed time 52 hour after the removal of the progestogen (the order in which the insemination was carried out was according to presentation of estrus), according to the procedure described by McKelvey et al. (1985) with refrigerated semen of Dorper sheep. In order to perform the insemination, the ewes were kept without food or water for 12 hours prior to the insemination. Between 15 and 19 days after insemination, the detection of estrus was carried out in rams, at 6:00 and 18:00h. 
The diagnostic of gestation to confirm the gestations was performed by ultrasound of real time and linear transductor of $7.5 \mathrm{Mhz}$ at 30 days post-insemination. The number of live lambs was registered at birthing. At the end of feed supplementation, a blood sample was taken and centrifuged at 3,500 rpm for 10 minutes to obtain blood plasma, which was then stored at $-80{ }^{\circ} \mathrm{C}$ until its analysis. The analysis of the total antioxidant capacity was carried out with a Total Antioxidant Capacity Assay Kit (Sigma Aldrich). For its interpretation, Trolox (6-hydroxy-2-5-7-8tetramethyl-croman-2-carboxylic acid) was used as standard, which is a hydrosoluble equivalent to Vitamin E.

For the quantitative determination in vitro of glucose and insulin in serum, a blood sample was obtained by jugular puncture from each ewe at the end of supplementation, in BD Vacutainer ${ }^{\circledR}$ tubes for serum. The tubes were centrifuged at 3,500 rpm for 10min and later analyzed. For glucose the reactive glucose-SL assay (DCL) was used, and an automatized biochemical analyzer ES-218 (Kontrol LAB) was employed. The quantification was made using the final point and kinetic methods, making the reading at a wavelength of $340 \mathrm{~nm}$. For insulin, Elisa was used with the kit ELISA insulin (Calbiotech). For the analysis of antioxidant capacity and glucose and insulin concentration, an analysis of variance was performed using the treatment as fixed effect. An analysis of variance was also made for dry matter consumption, with treatment as fixed effect and initial weight as covariable. A ji squared test was made to analyze the response to estrus, return to estrus, percentage of gestation at 35 days and prolificity, and an analysis of survival was applied to the variable hours at the onset of estrus (LIFESTAT, SAS 9.0). Comparison of means were made with Bonferroni tests.

\section{RESULTS AND DISCUSSION}

There was no statistical difference in the variables analyzed between the primiparous ewes that were in individual stalls and the multiparous ewes, thus they were grouped for the realization of the analysis, with the exception of feed intake, where only the data of the primiparous ewes were used. Feed intake was similar $(\mathrm{P}>0.05)$ between the control ewes (1.04 \pm 0.012) and those supplemented with dehydrated orange residue $(1.07 \pm 1.07)$. In growing lambs, it has been found that the inclusion of $15 \%$ orange silage in the diet improves food efficiency and weight gain (Gado et al., 2011). In fattening lambs, it has been reported that in a diet with $30 \%$ Buffel (Cenchrus ciliaria L.) hay, its replacement with fresh residue of the juice industry quadratically increases feed intake, with maximum consumption at $75 \%$ of replacement. The increment in consumption is attributed to the improvement in the quality of the orange fiber with respect to the grass (MacíasCruz et al., 2010). In lactating ewes, it has been demonstrated that it is possible to include $630 \mathrm{~g}$ of dry matter per day with a silage mixture containing $79.5 \%$ in moist orange base (Volanis et al., 2006). Therefore, it can be stated that the inclusion of orange residue does not have a negative effect on feed intake in ewes.

Of the 17 standards used with antioxidant capacity, 9 compounds were found at different concentrations. The compounds found in order of importance according to their percentage of the total of dry matter were hesperidin $(7.44 \%)$, chlorogenic acid $(0.50 \%)$, protocatechuic acid $(0.44 \%)$, galangin $(0.063 \%)$, syringic acid $(0.036 \%)$, naringenin $(0.023 \%)$, rutin $(0.012 \%)$, quercetin $(0.00657 \%)$ and phloridzin $(0.00033 \%)$. Similarly, Barrales et al. (2018) found that after extracting the juice and the oil from the orange residue, hesperidin is the phenolic compound with highest concentration. This flavonoid has been shown to exhibit strong antioxidant protection induced by the oxidant agents (Wilmsen et al., 2005).

The benefits in animal response have been demonstrated from the compounds found in the orange residue in the present study; for example, the consumption of $7 \mathrm{~g}$ per week of naringenin has been demonstrated to increment weight gain in lambs, while $14 \mathrm{~g}$ increments the concentration of the superoxide dismutase and the glutathione peroxidase (Alhidary and Abdelraham, 2016). When fattening chickens were supplemented with hesperidin and naringenin, it has been observed that the values of malondialdehyde (which is a metabolite of oxidation) decrease in the meat (Goliomytis et al., 2015). Hesperidin, naringenin and quercetin have been shown to reduce the concentrations of malondialdehyde, as well as increment the glutathione, glutathione peroxidase, glutathione reductase and glutathione transferase in laying hens (Iskender et al., 2016). In ewes it has been found that the inclusion of $6,000 \mathrm{mgkg}^{-1}$ 
of hesperidin or $6,000 \mathrm{mgkg}^{-1}$ of naringenin improves the oxidative stability of milk after day 14 of supplementation (Simitzis et al., 2019). Chlorogenic acid, second antioxidant compound with highest concentration found in this study, has been shown to improve growth and reduce the incidence of diarrhea in weaned piglets, as well as to increment the activity of the antioxidant enzymes such as superoxide dismutase, glutathione peroxidase and catalase (Chen et al., 2018); whereas in rats, protocatechuic acid has been shown to reduce the concentration of malondialdehyde induced by tert-Butyl hydroperoxide (Chuen-Lan et al., 2002).

It was found that the supplementation with orange residue 3 weeks prior to insemination did not affect $(\mathrm{P}>0.05)$ the response in estrus, given that $100 \%$ of the synchronized ewes presented receptiveness to the male. It was also observed that all of the ewes that did not return to estrus were diagnosed as pregnant on day 35 of gestation, thus no early loss of pregnancy occurred. Both the return to estrus and the percentage of gestation were similar $(\mathrm{P}>0.05)$ among treatments. No difference $(\mathrm{P}>0.05)$ was found for the onset of estrus. The average of estrus onset after removal of the CIDR was $27.77 \mathrm{~h}$ for the control treatment and $27.08 \mathrm{~h}$ for the treatment with inclusion of $20 \%$ dehydrated orange residue. In both treatments, the onset of estrus is some ewes began at 18 hours, with $100 \%$ of the ewes in estrus at 36 hours (Table 2).

A total of 35 births were registered; although numerically there was a tendency to increase the percentage of double births and therefore the prolificity with the inclusion of orange residue $(68.4 \%)$ with respect to the control treatment $(50 \%)$, statistically $(\mathrm{P}=0.14)$ there was no difference. With respect to the onset of estrus after removal of the instrument with progesterone, averages of $22.2 \mathrm{~h}$ are reported in ewes $5 / 8$ Pelibuey $x \quad 2 / 8$ Black Belly $x \quad 1 / 8$ Dorper synchronized with CIDR for 11 days plus $400 \mathrm{Ul}$ of eCG at the removal of the insert (ArroyoLedezma et al., 2013). In ewes synchronized for a short time with CIDR, onset of estrus is reported at $34.1 \mathrm{~h}$ with $400 \mathrm{Ul}$ of eCG (Martínez-Ros and Gonzalez-Bulnes, 2019) and 39.9 h with 380 Ul (Ungerfeld and Rubianes, 2002). In previous studies using another byproduct such as coffee pulp and synchronized with CIDR, we have reported averages of estrus onset of 31.6 to $34.9 \mathrm{~h}$ (Salinas-Rios et al., 2016) and of 32.7 to 34.8 hours depending on the treatment in Dorset cross ewes (Gutiérrez-Prado et al., 2019).

All of these averages are higher than those found in the present study; which may be due to the protocol of synchronization of estrus, given that it was found in both treatments. In tropical regions of Mexico, average conception rates have been reported in ewes inseminated by laparoscopy of $66.4 \%$ (Aké-Villanueva et al., 2017), similar to the average found in the present study. Flushing is important, given that an energetic supplementation prior to insemination increases the size of the follicles and the ovulation rate (Habibizad et al., 2015; Senosy et al., 2017). To this respect, Venter and Grayling (1994) recommend that it is not necessary to administer supplementation too early before synchronization especially if the ewes have good corporal condition. Therefore, we can assume that it is feasible to include $20 \%$ dry matter of orange residue without affecting the reproductive parameters in ewes, which would represent a reduction in the costs of feeding where there is availability of this byproduct.

Despite the large amount of antioxidant compounds in the orange residue, the antioxidant capacity of blood plasma of ewes supplemented with $20 \%$ dehydrated orange residue was similar $(\mathrm{P}>0.05)$ to that of the control ewes (Table 3). However, it is necessary to evaluate these residues in physiological stages where oxidative stress is increased. The glucose concentration and insulin was similar $(\mathrm{P}>0.05)$ in blood serum of ewes fed with $20 \%$ orange residue from juice stands and the controls (Table 3). Venter and Greyling (1994) report that the glucose concentration increases after the start of flushing. Similarly, it has been demonstrated that a high energy diet for a short period (four days before removal of the progestogen) increases the glucose concentrations (Senosy et al., 2017). The increase of glucose and insulin when there is a short period of supplementation regulates the development of the follicle (Viñoles et al., 2005). 
Table 2. Reproductive performance in hair ewes fed with the addition of $20 \%$ dry matter of orange residue prior to artificial insemination

\begin{tabular}{|c|c|c|c|}
\hline & T0 & T1 & $\mathrm{P}$ \\
\hline Response to estrus, $\%$ & 100 & 100 & 1 \\
\hline Return to estrus, $\%$ & $34.28(12 / 35)$ & $31.42(11 / 35)$ & 0.79 \\
\hline Hour of onset of estrus & $27.77 \pm 0.74$ & $27.08 \pm 0.79$ & 0.64 \\
\hline 18 hours, $\%$ & 2.86 & 11.42 & \\
\hline 24 hours, $\%$ & 42.85 & 31.42 & \\
\hline 30 hours, $\%$ & 42.85 & 51.42 & \\
\hline 36 hours, $\%$ & 11.42 & 5.71 & \\
\hline Percentage of gestation at 35 days, $\%$ & $66.6(23 / 35)$ & $68.57(24 / 35)$ & 0.79 \\
\hline Double births, $\%$ & $50(8 / 16)$ & $68.4(14 / 19)$ & 0.14 \\
\hline Prolificity & 1.50 & 1.73 & 0.14 \\
\hline
\end{tabular}

Table 3. Antioxidant capacity, glucose concentration and insulin in blood serum of hair ewes fed with the addition of $20 \%$ dehydrated orange residue prior to artificial insemination

\begin{tabular}{llll}
\hline Treatment & glucose $\mathrm{mmol} / \mathrm{L}$ & Insulin $\mathrm{pmol} / \mathrm{L}$ & Antioxidant capacity \\
\hline T0 & & (nmol/ $\mu$ l of Trolox) \\
T1 & $4.41 \pm 0.20$ & $12.94 \pm 0.94$ & $530.79 \pm 61.57$ \\
\hline
\end{tabular}

$\mathrm{T} 0=$ Control group; $\mathrm{T} 1=$ group fed with a diet with $20 \%$ dry matter of orange residue. \pm standard error. There were no differences $(\mathrm{P}>0.05)$.

Contrary to these authors, Mirzaei-Alamouti et al. (2018) found similar glucose concentrations when they supplemented with different sources of fatty acids prior to insemination with diets containing the same amount of energy and protein, which coincides with the present study. Therefore, the similarity in the glucose concentrations and insulin in the present study is due to the fact that isoprotein and isoenergetic diets were used, which indicates that the orange residue did not alter these concentrations. In dairy cows it has been observed that the glucose requirement increases when milk production increases. However, ruminants fed with fodder absorb little glucose from the digested starch, thus their requirements must be met through its synthesis in the liver using precursors such as propionate (Reynolds, 2006).

Therefore, in intensive sheep production systems where the sheep have a higher energy demand, due to the fact that the maximum number of weaned and heavier lambs is desired, the glucose requirements could be higher. Rumball et al. (2008) report that in early and intermediate gestation there is no difference in the glucose concentrations and insulin among singletonbearing and twin-bearing ewes; however, in late gestation the concentration of both is higher in singleton-bearing ewes. The increment of insulin in lactating cows increases the concentration of estradiol and IGF-1 without altering the pulsatile release of LH (Butler et al., 2004). There is little information in the literature about the use of orange byproducts and its effects on reproduction, thus the present study is important, given that it demonstrates that its inclusion at $20 \%$ is possible in reproductive ewes. This is very important, given that it can reduce feeding costs with a byproduct, which according to samplings we have carried out, represents approximately $50 \%$ of the entire orange.

\section{CONCLUSION}

The addition of $20 \%$ of orange residues in the diet of sheep prior to artificial insemination does not affect reproductive performance, glucose and insulin levels, nor the antioxidant capacity in hair ewes, however, they are an alternative to reduce the feed costs when this by-product is available. 


\section{REFERENCES}

AKÉ-VILLANUEVA, J.R.; AKÉ-LÓPEZ, J.R.; SEGURA-CORREA, J.C. et al. Factors affecting conception rate of hair ewes after laparoscopic insemination with chilled semen under tropical conditions. Small Ruminant Res., v.153, p.114$117,2017$.

ALHIDARY, I.A.; ABDELRAHAM M.M. Effects of naringin supplementation on productive performance antioxidant status and immune response in heat-stressed lambs. Small Ruminant Res., v.138, p.31-36, 2016.

ARROYO-LEDEZMA， J.; DE LA TORREBARRERA J.; ÁVILA-SERRANO. Respuesta reproductiva de ovejas de pelo sincronizadas con progesterona o prostaglandinas. Agrociencia, v.47, p.661-670, 2013.

BARRALES, F.M.; SILVEIRA, P.; MENEZES, B.P. et al. Recovery of phenolic compounds from citrus by-products using pressurized liquids - an application to orange peel. Food Bioprod. Process, v.112, p.9-21, 2018.

BOSCARO, C.F.A.; AZAMBUJA, R.E.L.; YURIKA, M.I. et al. Influence of pre and postnatal energy restriction on the productive performance of ewes and lambs. Rev. Bras. Zootec., v.41, p.951-958, 2012.

BUTLER, S.T.; PELTON, S.H.; BUTLER W.R. Insulin increases $17 \mathrm{~b}$-estradiol production by the dominant follicle of the first postpartum follicle wave in dairy cows. Reproduction, v.127, p.537545, 2004.

CHEN, J.; LI, Y.; CHEN, D. et al. Dietary chlorogenic acid improvesgrowth performance of weaned pigs through maintaining antioxidant capacity and intestinal digestion and absorption function. J. Anim. Sci., v.96, p.1108-1118, 2018.

CHUEN-LAN, L.; JIN-MING, W.; CHIA-YIH, C. et al. In vivo protective effect of protocatechuic acid on tert-butyl hydroperoxide-induced rat hepatotoxicity. Food Chem. Toxicol., v.40, p.635641, 2002.

ESCOBEDO-AVELLANEDA， Z.; GUTIERREZURIBE, J.; VALDEZ-FRAGOSO, A. Phytochemicals and antioxidant activity of juice, flavedo, albedo and comminuted orange. J. Funct. Foods, v.6, p.470-481, 2014.
FOOD and Agriculture Organization of the United Nations. Citrus fruit fresh and processed, statistical bulletin. Roma: FAO, 2017.

GADO, H.M.; SALEM, A.Z.M.; ODONGO, N.E.; BORHAMI, B.E. Influence of exogenous enzymes ensiled with orange pulp on digestion and growth performance in lambs. Anim. Feed Sci. Technol., v.165, p.131-136, 2011.

GOLIOMYTIS, M.; KARTSONAS, N.; CHARISMIADOU, M.A. et al. The influence of naringin or hesperidin dietary supplementation on broiler meat quality and oxidative stability. PLoS ONE, v.10, p.1-11, 2015.

GUTIÉRREZ-PRADO, L.K.; SÁNCHEZTORRES-ESQUEDA, M.T.; SALINAS-RIOS, T. et al. Coffee pulp supplementation prior to breeding improves oxidative status without affecting fertility of primiparous ewes. Rev. Colomb. Cienc. Рecu., v.32, p.261-273, 2019.

HABIBIZAD, J.; RIASI, A.; KOHRAM, H.; RAHMANI, H.R. Effect of long-term of shortterm supplementation of high energy or high energy-protein diets on ovarian follicles and blood metabolites and hormones in ewes. Small Ruminant Res., v.132, p.37-43, 2015.

ISKENDER, H.; YENICE, G.; DOKUMACIOGLU, E. et al. The effects of dietary flavonoid supplementation on the antioxidant status of laying hens. Braz. J. Poult. Sci., v.18, p.663-668, 2016.

KHURSHEED, N.S.M.; SEJIAN, V.Y.; ABDUL, K.S. Effect of feed flushing during summer season on growth, reproductive performance and blood metabolites in Malpura ewes under semiarid tropical environment. Trop. Anim. Health Prod., v.45, p.143-148, 2013.

MACÍAS-CRUZ, U.; QUINTERO-ELISEA, J.A.; AVENDAÑO-REYES, L. et al. Buffelgrass (Cenchrus ciliaria L.) substitution for orange pulp on intake, digestibility, and performance of hair sheep lambs. Trop. Anim. Healt Prod., v.42, p.223-232, 2010.

MARTÍNEZ-ROS, P.; GONZALEZ-BULNES, A. Efficiency of CIDR-based protocols including $\mathrm{GnRH}$ instead of Ecg for estrus synchronization in sheep. Animals, v.9, p.146, 2019. 
MCKELVEY, W.A.C.; ROBINSON, J.J.; AITKEN, R.P.; HENDERSON, G. The evaluation of a laparoscopic insemination technique in ewes. Theriogenology, v.24, p.519535,1985

MIRZAEI-ALAMOUTI, H.; MOHAMMADI, Z.; SHAHIR, M.H. et al. Effects of short-term feeding of different sources of fatty acids in premating diets on reproductive performance and blood metabolites of fat-tailed Iranian Afshari ewes. Theriogenology, v.113, p.85-91, 2018.

NORDI, E.C.P.; COSTA, R.L.D.; DAVID, C.M.G. et al. Supplementation of moist and dehydrated citrus pulp in the diets of sheep artificially and naturally infected withgastrointestinal nematodes on the parasitological parameters and performance. Vet. Parasitol., v.205, p.532-539, 2014.

OFFICIAL methods of analysis. 15ed. Washington: AOAC, 1990. 1298p.

REYNOLDS, C.K. Production and metabolic effects of site of starch digestion in dairy cattle. Anim. Feed Sci. Technol., v.130, p.78-94, 2006.

RUMBALL, C.W.H.; HARDING, J.E.; OLIVER, M.H.; BLOOMFIELD, F.H. Effects of twin pregnancy and periconceptional under nutrition on maternal metabolism, fetal growth and glucose-insulin axis function in ovine pregnancy. J. Physiol., v.586, p.1399-1411, 2008.

RUSSEL, A.J.F.; DONEY, J.M.; GUNN R.G. Subjective assessment of fat in live sheep. $J$. Agricult. Sci., v.72, p.451-454, 1969.

SALINAS-RIOS, T.; SÁNCHEZ-TORRESESQUEDA, M.T.; DÍAZ-CRUZ, A. et al. Oxidative status and fertility of ewes supplemented coffee pulp during estrous synchronization and early pregnancy. Rev. Colomb. Cienc. Pecu., v.29, p.255-263, 2016.

SALVADOR, A.; IGUAL, M.; CONTRERAS, C. et al. Effect of the inclusion of citrus pulp in the diets of goats on cheese characteristics. Small Ruminant Res., v.121, p.361-367, 2014.

SENOSY, W.; MAHMOUD, G.B.; ABDELRAHEEM S.M. Influence of short-term energy supplementation on estrus, ovarian activity, and blood biochemistry in Ossimi ewes synchronized with fluorogestone acetate in the subtropics. Theriogenology, v.15, p.152-157, 2017.
SEOK-MOON, J.; SO-YOUNG, K.; DONGRYUL, K. et al. Effect of heat treatment on the antioxidant activity of extracts from citrus peels. J. Agric. Food Chem., v.52, p.3389-3393, 2004.

SIMITZIS, P.; MASSOURAS, T.; GOLIOMYTIS, M. et al. The effects of hesperidin or naringin dietary supplementation on the milk properties of dairy ewes. J. Sci. Food Agric., v.99, p.6515-6521, 2019.

TADAYON, Z.; ROUZBEHAN, Y.; REZAEI, J. Effects of feeding different levels of dried orange pulp and recycled poultry bedding on the performance of fattening lambs. J. Anim. Sci., v.95, p.1751-1765, 2017.

UGERFELD, R.; RUBIANES, E. Short term primings with different progestogen intravaginal devices (MAP, FGA and CIDR) for eCG-estrous induction in anestrus ewes. Small Ruminant Res., v.46, p.63-66, 2002.

VAN SOEST, P.J.; ROBERTSON, J.B.; LEWIS, B.A. Methods for dietary fiber, neutral fiber and nostarch polysaccharides in relation to nutrition. J. Dairy Sci., v.74, p.3583-3597, 1991.

VEENA, B.S.; UPADHYA, S.; KUMAR, A.S.; PRATAP, K.N. Evaluation of oxidative stress, antioxidants and prolactin in infertile women. Indian J. Clin. Biochem., v.23, p.186-190, 2008.

VENTER, J.L.; GREYLING, J.P.C. Effect of different periods of flushing and synchronized mating on body weight, bloodglucose and reproductive performance in spring-mated ewes. Small Ruminant Res., v.13, p.257-261, 1994.

VIÑOLES, C.; FOSBERG, M.; MARTIN, G.B. et al. Short-term nutritional supplementation of ewes in low body condition affects follicle development due to an increase inglucose and metabolic hormones. Reproduction, v.129, p.299309, 2005.

VOLANIS, M.; ZOIOPOULOS, P.; PANAGOU, E.; TZERAKIS, C. Utilization of an ensiled citrus pulp mixture in the feeding of lactanting dairy ewes. Small Ruminant Res., v.64, p.190-195, 2006.

WILMSEN, P.K.; SPADA, D.S.; SALVADOR M. Antioxidant Activity of the flavonoid hesperidin in chemical and biological systems. $J$. Agric. Food Chem., v.53, p.4757-4761, 2005. 